
компетенции магистров экономических специальностей с помощью учебно-ролевых игр

Тульский государственный университет, пр. Ленина, 92, г. Тула, 300012, Россия galinasem27.03@mail.ru

Статья поступила 08 октября 2019; принята 30 ноября 2019; опубликована 31 декабря 2019

Аннотация. В соответствии с требованиями современного профессионального рынка выпускникам неязыковых вузов необходимо иметь сформированную профессиональную иноязычную коммуникативную компетенцию, которая позволит им эффективно функционировать в академической и профессиональной среде. Выпускник магистратуры должен удовлетворять требованиям, предъявляемым к квалифицированному специалисту (в том числе, со стороны работодателя) в области использования иностранного языка. При изучении магистрантами иностранного языка первостепенное значение приобретает овладение ими терминологией будущей профессиональной деятельности для реализации себя в различных ситуациях делового и профессионального иноязычного общения. Цель статьи заключается в том, чтобы рассмотреть ролевую игру как эффективный метод формирования профессиональной иноязычной коммуникативной компетенции при обучении иностранному языку магистров экономических специальностей. Автор представляет различные классификации учебноролевых игр, их функции, требования к их организации, а также аспекты профессионально ориентированных учебных ситуаций. На примере учебноролевой игры в форме научно-практической конференции подробно освещены ее этапы и функции. Результативность процесса формирования профессиональной иноязычной коммуникативной компетенции магистров экономических специальностей проверялась с помощью методов анкетирования, тестирования, педагогического наблюдения, беседы. В заключении автор приходит к выводу, что ролевая игра является моделью общения, имеет много возможностей и характеристик, мотивирует магистров принимать активное участие в выполнении заданий в рамках поставленной профессионально ориентированной учебной ситуации, способствует расширению ассоциативной базы в процессе усвоения нового материала, создаёт положительную атмосферу на занятии и обеспечивает гармоничную коллективную деятельность, а значит - повышает эффективность обучения иностранному языку магистров экономических специальностей.

Ключевые слова: профессиональная иноязычная коммуникативная компетенция; магистры экономических специальностей; неязыковой вуз; профессиональная компетенция; учебно-ролевая игра, деловая игра. 
Информация для цитирования: Семенова Г.В. Формирование профессиональной иноязычной коммуникативной компетенции магистров экономических специальностей с помощью учебно-ролевых игр // Научный результат. Педагогика и психология образования. 2019. Т.5. №4. C. 29-42. DOI: 10.18413/23138971-2019-5-4-0-3

\title{
G.V. Semenova \\ Formation of professional foreign language communicative competence of master's degree students of economic specialties with the help of educational role-playing games
}

\author{
Tula State University, \\ 92, Lenin Ave., Tula, 300012, Russia \\ galinasem27.03@mail.ru
}

Received on October 08, 2019; accepted on November 30, 2019; published on December 31, 2019

\begin{abstract}
In accordance with the requirements of the modern professional market, graduates of non-linguistic universities need to have a well-formed professional foreign language communicative competence, which will allow them to function effectively in the academic and professional environment. A master's degree graduate must meet the requirements of a qualified specialist (including the employer) in the use of a foreign language. When studying a foreign language by undergraduates, mastering the terminology of their future professional activity for the realization of themselves in various situations of business and professional foreign language communication is of paramount importance. The purpose of the article is to consider role-playing as an effective method of formation of professional foreign language communicative competence when teaching a foreign language to master's degree students of economic specialties. The author presents various classifications of educational role-playing games, their functions, requirements for their organization, as well as some aspects of professionally oriented educational situations. On the example of an educational role-playing game in the form of a scientific conference, its stages and functions are described in detail. The effectiveness of the process of formation of professional foreign language communicative competence of master's degree students of economic specialties was checked using the methods of questioning, testing, pedagogical observation, conversation. The author comes to the conclusion that role play is a model of communication, it has many features and characteristics that motivate master's degree students to take an active part in performing tasks within the framework of their professional-oriented learning situations, and contributes to the expansion of the associative base in the process of learning new material, creates a positive atmosphere in the class-room, creates a harmonious collective activity, and raises the efficiency of foreign language teaching.
\end{abstract}

Keywords: professional foreign language communicative competence; master's degree students of economic specialties; non-linguistic University; professional competence; educational role-playing game, business game.

Information for citation: Semenova, G.V. (2019), "Formation of professional foreign language communicative competence of master's degree students of economic 
specialties with the help of educational role-playing games", Research Result. Pedagogy and Psychology of Education, 5 (4), 29-42, DOI: 10.18413/2313-8971-2019-54-0-3

Введение (Introduction). Современный этап обучения иностранному языку студентов неязыковых специальностей характеризуется усилением внимания к использованию интерактивного подхода, в частности, с целью более эффективного формирования профессиональной иноязычной коммуникативной компетенции обучаемых. К будущим специалистам, выпускникам высших учебных заведений, в условиях развития международных экономических отношений, предъявляются новые, более сложные, требования к реализации собственного профессионального потенциала, поэтому одной из главных задач образовательной системы на сегодняшний день является повышение эффективности обучения за счет применения различных методов, ориентированных на формирование основных компетенций, и их адаптирования к современным экономическим и социальным моделям. В соответствии с требованиями современного профессионального рынка, а также обращая внимание на тот факт, что английский язык является международным языком общения в различных отраслях, выпускники неязыковых вузов должны иметь сформированную профессиональную иноязычную коммуникативную компетенцию, которая позволит им эффективно функционировать в академической и профессиональной среде.

Профессиональная компетенция современного экономиста состоит не только из специальных знаний и умений, но и из личностных компетенций: хорошее развитие концентрации и переключения внимания (способность в течение длительного времени сосредоточиваться на одном предмете и быстро переходить с одного вида деятельности на другой), высокий уровень развития памяти, высокий уровень математических (счетных) способностей, способность работать в условиях дефицита времени и информации, способность длительное время заниматься однообразным видом деятельности (работа с документами, текстами, цифрами), аналитическое мышление (Корниенко, 2014). Во время обучения иностранному языку необходимо учитывать все вышеперечисленные факторы, что даст возможность студентам развиваться всесторонне в профессиональном направлении. Один из способов, в котором можно задействовать все необходимые будущему специалисту компетенции - это использование учебно-ролевых игр во время процесса обучения иностранному языку в неязыковом вузе.

Актуальность данной работы обусловлена тем, что формирование и совершенствование профессиональных иноязычных речевых навыков и умений студентов возможно только при условии практического применения языка в процессе обучения, что предполагает моделирование реальных учебных, профессиональных и бытовых ситуаций на занятиях, которые имитируют в форме игры общение современного человека в различных сферах жизни.

Основная часть (Main Part). Цель статьи заключается в том, чтобы рассмотреть ролевую игру как эффективный метод формирования профессиональной иноязычной коммуникативной компетенции при обучении иностранному языку магистров экономических специальностей.

Для достижения цели следовало решить следующие задачи:

- изучить такой метод активного обучения как ролевая игра;

- определить преимущества применения ролевой игры в процессе формирования профессиональной иноязычной коммуникативной компетенции студентов в неязыковом вузе;

- описать возможности использования данного метода наряду с традиционными в процессе обучения иностранному языку студентов неязыкового вуза. 
Научная новизна использования ролевой игры на занятиях по иностранному языку в неязыковом вузе заключается в усилении мотивации и интереса студента к профессии и изучению профессионального иностранного языка, благодаря созданию реальной имитируемой действительности.

Теоретическая основа и методология. Вопрос введения в учебный процесс методов активного обучения, а именно использование учебно-ролевых игр для моделирования профессиональной ситуации с помощью иностранного языка, освещается в научно-методических публикациях многих зарубежных и отечественных ученых, среди которых А.А. Деркач, С.Д. Щербак, Т.И. Олейник, Г.М. Тер-Саакянц, О.И. Вишневский, Ю.И. Мешенева, Е.А. Нелюбина, Ю.В. Павловская, Г.М. Чудайкина, Н.Ю. Логинова, В.В. Костоварова, В. Авз, Д. Бетеридж, К. Ливингстоун, А. Малей, Д. Хандфильд и другие.

Среди ученых пока не существует единого определения понятия «ролевая игра», более того могут встречаться различные названия этого вида деятельности, среди которых: учебно-ситуативная игра (М.Ф. Стронин), ситуативно-имитационная (Ш.В. Драгомирецкий), деловая (О.Н. Краснянская), ролевая игра (О.Г. Штепа, Т.И. Олейник). Одни авторы описывают ролевую игру как активный метод обучения, другие - как методический прием.

В статье за основу взято определение согласно новому словарю методических терминов и понятий: «ролевая игра - это форма организации коллективной учебной деятельности на занятиях по иностранному языку, имеющая своей целью формирование и развитие речевых навыков и умений в условиях, максимально близких к условиям реального общения» (Азимов Э.Г., Щукин A.H., 2009).

По содержанию ролевые игры могут делиться на следующие груnпь: 1) социальные; 2) бытовые; 3) учебные; 4) деловые. Однако существуют различные классификации обучающих игр (Ярунина, 2017). Например, Т.И. Олейник разделяет игры по трём признакам (по учебной цели, количеству участников, уровню самостоятельности), а В.И. Вишневский выделяет четыре группы игр: языковедческие, условнокоммуникативные, коммуникативные и имеющие индивидуальное или коллективное направление. Наиболее полную классификацию учебно-ролевых игр, на наш взгляд, предлагают А.А. Деркач и С.Д. Щербак. Они разделяют ролевые игры таким образом:

- по количеству участников (индивидуальные, парные, групповые и др.);

- по функции (подготовительные, контрольные);

- по степени сложности (простые, сложные, моноситуативные, полиситуативные);

- $\quad$ по типу задачи (оперативные, тактические, стратегические);

- $\quad$ по продолжительности проведения (долгосрочные, краткосрочные);

- по содержанию и цели (аспектные, языковые, коммуникативные);

- по уровню сложности индивидуальной деятельности (репродуктивные, репродуктивно-вариативные, творческие);

- $\quad$ по способу, характеру, форме проведения (письменные, устные, ролевые, предметные, имитационно-моделирующие и т. п.) (Деркач, Щерба, 1991).

Ролевые игры на занятиях по иностранному языку в неязыковом вузе способствуют решению важных методических задач:

- повышение мотивации к изучению языка;

- понимание студентами практической значимости изучаемого материала;

- проявление творческого потенциала студентов;

- многократное повторение определенных языковых образцов;

- воспитание культуры общения;

- формирование умений работать в команде;

- психологическая готовность к общению на иностранном языке; 
- совершенствование умений оценивать результаты своей работы.

Функиии учебно-ролевой игры, по мнению В. Л. Скалкина, следующие:

- обучающая (способствует овладению навыками и умениями иноязычной коммуникации);

- мотивационно-стимулирующая (мотивирующая и стимулирующая учебнопознавательная деятельность);

- таргетинг (ориентирует участников на планирование собственного речевого поведения и на предсказание поведения других коммуникантов);

- компенсаторная (компенсирует отсутствие общения в реальных ситуациях);

- воспитательная (способствует формированию личности, расширяет мировоззрение) (Скалкин, 2005: 95).

Профессиональная иноязычная коммуникативная компетенция формируется на протяжении всех этапов обучения студента в неязыковом вузе: в бакалавриате, магистратуре, аспирантуре. На этапе бакалаврской подготовки обучающиеся только начинают знакомиться с азами своей будущей профессиональной деятельности, поэтому на занятиях по иностранному языку и в самостоятельной работе студентам предлагается чтение и анализ аутентичных текстов по широкому профилю специальности. Магистратура и аспирантура имеют узкопрофессиональную направленность. При поступлении в магистратуру бакалавр выбирает специализацию, и именно в магистратуре начинается реальное обучение в узкопрофессиональном контексте. Выпускник магистратуры должен удовлетворять требованиям, предъявляемым к квалифицированному специалисту (в том числе со стороны работодателя) в области использования иностранного языка. Поэтому при изучении студентами-магистрантами иностранного языка первостепенное значение приобретает овладение ими терминологией будущей профессиональной деятельности для реализации себя в таких ситуациях делового и профессионального иноязычного общения, как:

- участие в международных проектах по разработке новых технологий, реализуемых международными организациями;

- партнёрское участие в работе зарубежных научно-исследовательских лабораторий во время научных стажировок;

- у участие в выставочной работе;

- участие в работе научных, научнопроизводственных, научно-практических и научно-исследовательских семинаров;

- подготовка и презентация аналитических отчётов, докладов (устных и стендовых), а также результатов исследования на научных конференциях и симпозиумах;

- участие в деятельности профессиональных сетевых сообществ по конкретным направлениям развития предметной области;

- участие в организации международного сотрудничества в рамках функционирования высших учебных заведений и научно-технических центров;

- изучение научных результатов, сбор и анализ научной литературы, научноисследовательских проектов в соответствии с профилем подготовки;

- изучение, анализ и обобщение зарубежного опыта по тематике исследования;

- сбор и анализ информации на иностранном языке в сфере профессиональной деятельности;

- изучение научных результатов, сбор и анализ научной литературы или научно-исследовательских проектов в соответствии с профилем профессиональной деятельности;

- составление научных аннотаций, пояснительных записок, информационных материалов, рефератов и библиографии по тематике проводимых исследований;

- подготовка, рецензирование, редактирование и оформление научных и научно-технических публикаций и обзоров в зарубежных изданиях;

- подготовка технических отчетов и другой технической документации; 
- реферирование научных трудов, составление аналитических обзоров, накопленных в мировой науке и производственной деятельности;

- составление заявок на патенты, изобретения, открытия и промышленные образцы;

- составление инструкций по эксплуатации оборудования и программ испытаний;

- составление аналитических справок, экспертных заключений, прогнозов;

- подготовка и проведение анкетирования и опросов;

- $\quad$ подготовка бизнес-планов;

- $\quad$ оформление патентов;

- подготовка заключений на рационализаторские предложения и изобретения (Семенова, 2018: 95-97).

Согласно стандартным требованиям к получению степени магистра, уровень владения иностранным языком у обучающегося предполагает, что магистрант может:

- понимать широкий спектр довольно сложных и объемных текстов и распознавать имплицитное значение выражений;

- выражаться быстро и спонтанно без заметных затруднений, связанных с поиском средств выражения;

- эффективно и гибко пользоваться языком в учёбе, общественной и профессиональной жизни;

- чётко, логично, подробно высказываться на сложные темы, демонстрируя сознательное владение грамматическими структурами, профессиональной лексикой и правилами построения связного высказывания (Кондюрина, Гришина, Шевелева, 2018).

Для формирования профессиональной иноязычной коммуникативной компетенции студента большую эффективность имеет ролевая игра, имитирующая реальную профессиональную деятельность (деловая игра). Это метод, с помощью которого возможно моделирование проблемной профессиональной ситуации, решение которой достигается в процессе ролевого взаимодей- ствия участников, по правилам, с формированием команд игроков и «группы экспертов», в соответствии с сюжетом, по определенному сценарию и последующей оценкой принятого решения. Разыгрываемая ситуация должна предполагать неоднозначность решений, содержать элемент неопределенности, что обеспечивает проблемный характер игры и личностное участие обучающихся.

Деловые игры на иностранном языке, разработанные на конкретных ситуациях, вводят обучающихся в сферу профессиональной деятельности, являясь мощным стимулом активизации самостоятельной работы по приобретению профессиональных иноязычных знаний и навыков, а также способности решать нестандартные профессиональные задачи.

Интерактивное взаимодействие происходит в процессе всей деловой игры, так как решения принимаются преимущественно коллективно. При этом каждый решает свою отдельную задачу в соответствии со своей ролью и функцией. Обучающиеся приобретают социальные навыки, развивают коммуникативные иноязычные способности, критическое мышление для принятия профессионально грамотных решений. Эффективность обучения здесь обусловлена, в первую очередь, взрывом мотивации, повышением интереса к предмету. Ролевая игра мотивирует иноязычную речевую деятельность, так как обучаемые оказываются в ситуации, когда актуализируется потребность что-либо сказать, спросить, выяснить, доказать, чем-то поделиться с собеседником.

Учитывая вышеизложенную информацию, считаем метод использования учебноролевых игр, в частности, деловых, приоритетным для успешного формирования профессиональной коммуникативной иноязычной компетенции, которая позволяет формировать способность говорить, читать и писать на иностранном языке и понимать иноязычную речь на слух в области профессионального языка, то есть научить пользоваться специальным иностранным языком для решения коммуникативных профессио- 
нальных задач. Многие специалисты (Нелюбина, 2014; Павловская, 2016; Чудайкина, 2017; Деркач, Щерба, 1991; Курченкова, 2016; Юханов, Гордеев, 2008 и др.) считают, что использование учебно-ролевых (деловых) игр способствует не только формированию навыков аудирования, говорения, чтения и письма, но и помогает студентам глубже овладеть своей специальностью (предоставление иноязычного профессионально-ориентированного материала), формирует устойчивые речевые навыки и гибкие стереотипы в ситуациях, максимально приближенных к действительности. Кроме того, использование учебно-ролевых игр дает возможность сформировать личные качества, необходимые будущим специалистам в дальнейшей профессиональной деятельности, повышает мотивацию, в частности, оживляет занятия и стимулирует позитивное отношение к изучаемому языку. Чувство равенства, атмосфера увлечённости и радости, ощущение посильности заданий всё это даёт возможность студентам преодолеть стеснительность, мешающую свободно употреблять в речи слова чужого языка и благотворно сказывается на результатах обучения. Незаметно усваивается языковой материал, а вместе с этим возникает чувство удовлетворения - оказывается, я могу говорить наравне со всеми (Исламова, 2016: 140).

Результаты исследования и их обсуждение. Для достижения цели настоящего исследования в ходе профессиональноориентированной языковой подготовки с целью формирования готовности к профессиональному межличностному общению специалистов в экономической сфере нами применялся на практических занятиях помимо традиционных методов обучения комплекс ролевых и деловых игр, поскольку игровая деятельность имитирует профессиональную речевую деятельность, подобную реальной.

Для участия в педагогическом эксперименте по выявлению эффективности применения ролевых игр при обучении иностранному языку были привлечены группы магистрантов, проходящих обучение в Институте права и управления Тульского государственного университета по направлению «Менеджмент». Эмпирическую базу педагогического эксперимента составили 28 студентов, которые были поделены на экспериментальную и контрольную группы.

На первом этапе эксперимента была проведена оценка фактического исходного уровня сформированности профессиональной иноязычной коммуникативной компетенции, уровня мотивации к обучению, степени вовлеченности в процесс обучения и интереса к изучению предмета у магистрантов контрольной и экспериментальной групп, с помощью методов анкетирования и тестирования было выявлено, что эти показатели у всех испытуемых примерно одинаковые (рис. 1).

Магистранты экспериментальной группы принимали участие в апробации ролевых (деловых) игр на занятиях по иностранному языку. Магистранты контрольной группы занимались на основе традиционных методов обучения.

Отличительной особенностью профессионально-ориентированного обучения иностранному языку магистров экономических специальностей является максимальный учет специфики их профессиональной сферы: ее концептов и терминологии, лексикосинтаксических и грамматических особенностей, формата устных и письменных текстов, ситуативных особенностей.

Магистранты экспериментальной и контрольной групп изучали профессиональную лексику, читали тексты профессиональной направленности, готовили собственные проекты на иностранном языке. Все обучаемые осваивали одинаковый объем материала, им было выделено одинаковое количество аудиторных часов.

В экспериментальной группе наряду с традиционными технологиями обучения применялись деловые игры. Используя метод педагогического наблюдение, автор выявил, что при применении деловой игры вовлечение в процесс обучения каждого было полным. 


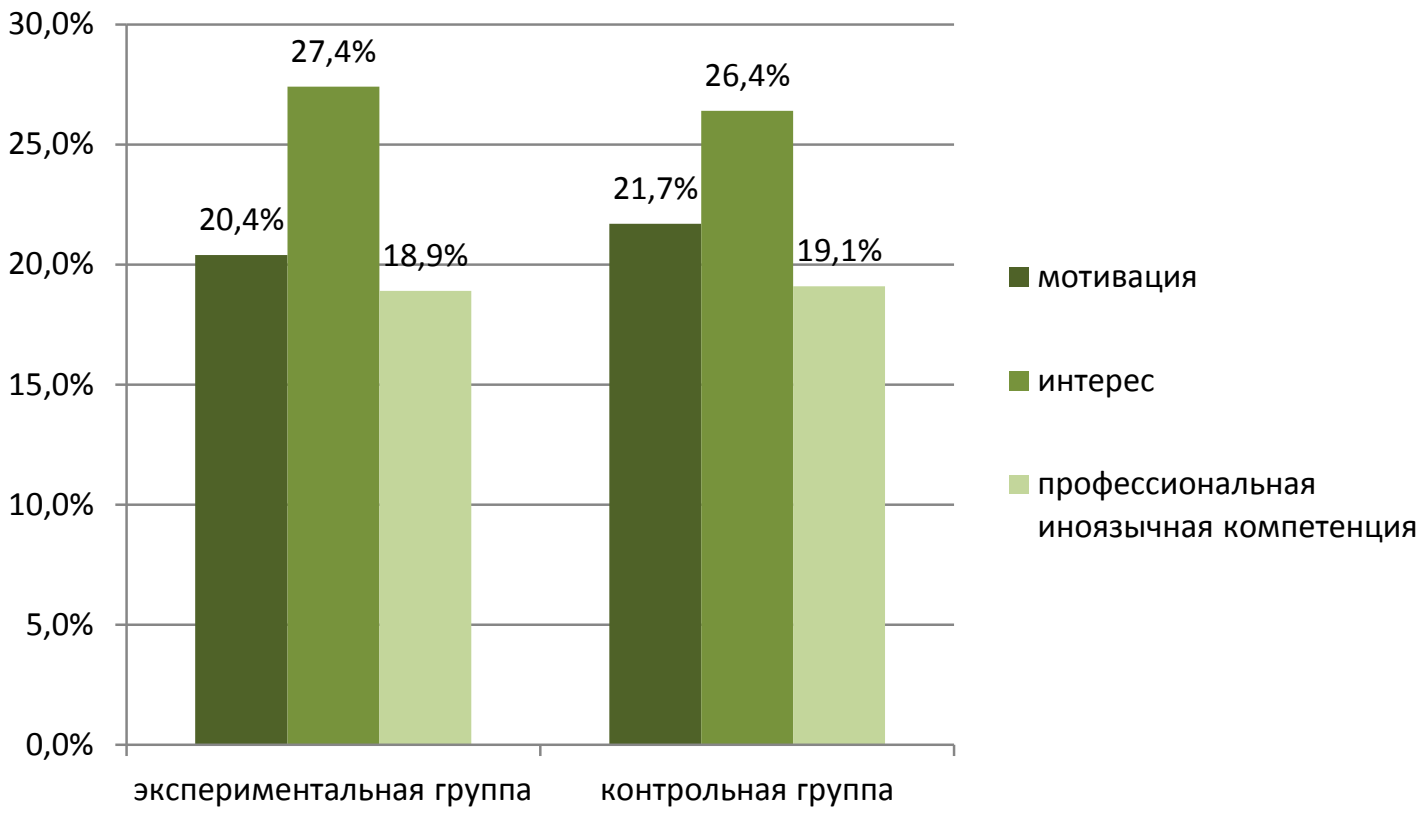

Рис. 1. Исходный уровень сформированности профессиональной иноязычной коммуникативной компетенции, мотивации к обучению, степени вовлеченности в процесс обучения и интереса к изучению предмета

Fig. 1. The initial level of formation of professional foreign-language communicative competence and learning motivation, the degree of involvement in the learning process and interest in the study of the subject

В экспериментальной группе наряду с традиционными технологиями обучения применялись деловые игры. Используя метод педагогического наблюдение, автор выявил, что при применении деловой игры вовлечение в процесс обучения каждого было полным.

Чтобы использование ролевой (деловой) игры было эффективным, при организации материала должны быть учтены:

1. Цель игры. Учебно-ролевая игра должна четко соответствовать цели занятия. Например, готовя материал по теме «Negotiations», преподавателю необходимо обратить особое внимание на поставленные задачи и удостовериться, что они могут быть решены именно с помощью определённой учебно-ролевой игры.

2. Актуальность. Учебно-ролевая игра должна быть актуальной, соответствовать последним тенденциям профессиональной сферы магистрантов. То есть, при подготовке занятия по теме «Management» необхо- димо использовать самые новые материалы. Это не только будет способствовать профессиональному развитию студентов, но и повысит их мотивацию к изучению иностранного языка.

3. Профессиональные компетенции. С помощью учебно-ролевой игры должны быть проиллюстрированы типичные профессиональные ситуации и несколько профессиональных аспектов. Например, занятие по теме «Employment trends» можно дополнить ролевыми играми, которые непосредственно будут покрывать все ключевые аспекты процесса принятия на работу (арplication for a job, an interview, etc).

4. Социокультурные компетенции. Ролевая игра должна содержать элемент социального тренинга, необходимый для формирования социальных навыков общения.

5. Индивидуальные особенности обучаемого. Преподаватель должен распределять роли, учитывая не только лингвистическую компетенцию, но и индивидуально- 
психологические особенности каждого студента (Livingstone, 1983: 46) таким образом, чтобы студент чувствовал себя естественно, был заинтересован и имел возможность продемонстрировать свои творческие способности.

Ролевая игра имитирует модели реальных ситуаций и проблем. Однако, это не просто репетиция ситуаций из будущей реальной жизни, это средство выйти за рамки ограниченного общения в аудитории. Приведем несколько примеров видов учебной работы в режиме ролевой игры, предлагаемых магистрантам экономического профиля в экспериментальной группе:

- решение профессионально значимых задач (что необходимо сделать, чтобы убедить деловых партнеров принять Ваше предложение на размещение заказа; убедить противоположную сторону в необходимости $10 \%$ скидки на поставляемый товар и т.д.);

- обсуждение конкретного проекта (составление таблиц, схем, рассмотрение экономических характеристик проекта);

- просмотр видеосюжета с последующим заданием, типа: "Чтобы Вы сделали, оказавшись в подобной ситуации?"

Очень важное значение имеет и роль преподавателя в ходе проведения учебноролевой игры. В процессе игры она постоянно меняется. Если сначала он активно контролирует деятельность участников, то постепенно его роль сводится к роли активного наблюдателя. Прямое вмешательство преподавателя в ход игры, например, исправление ошибок, может ограничить свободу действий магистров и замедлить игровую деятельность. Идеальная роль преподавателя - это роль фасилитатора, который подсказывает соответствующее слово или фразу (Brumfit, Johnson, 2008: 124), направляет участников и следит, чтобы выполнялись все установленные правила учебноролевой игры.

Известный педагог Ладусс выявил 11 факторов в ролевых играх (Ladousse, 1987). Эти факторы: уровень, время, цель, язык, организация, подготовка, разминка, про- цесс, последующий анализ, анализ и замечания, вариабельность.

Предлагаем рассмотреть учебноролевую (деловую) игру в виде научнопрактической конференции по теме «External economic activity at the enterprise», coзданную для магистров экономических специальностей с учётом формирования их профессионально-личностных компетенций и профессиональной иноязычной коммуникативной компетенции и на основе факторов, предложенных Ладуссом.

Так как система научно-исследовательской работы студентов представляет собой совокупность мероприятий, направленных на освоение студентами в процессе обучения методов, приемов и навыков выполнения научно-исследовательских работ, развитие способностей к научному и техническому творчеству, самостоятельности и инициативы (Семенова, 2015: 136), то мы выбрали в качестве ролевой игры проведение научно-практической конференции на иностранном языке по профилю специальности. Преподаватель всегда должен чётко представлять, соответствует ли игра профессиональному уровню подготовки магистрантов, уделить особое внимание именно оптимальному выбору вида ролевой игры, поскольку нецелесообразно ставить задачи или предлагать тему разговора, которая выходит за рамки приобретенных знаний (Littlewood, 2007: 71).

Уровень. Данная деловая игра предполагает высокий уровень владения иностранным языком, что соответствует уровню иноязычной подготовки магистрантов.

Время в нашем случае зависит от протяженности пары в учебном процессе вуза, то есть 1 час 30 минут.

Цель учебно-ролевой игры по теме «External economic activity at the enterprise» заключается в развития профессиональноличностных компетенций магистров, их иноязычной профессиональной коммуникативной компетенции, в укреплении уверенности в себе, в развитии «чувства» языка.

Язык. Разнообразие ролей помогает решить проблему неоднородности группы 
по уровню языковой подготовки каждого магистранта и его индивидуальных особенностей. Данная деловая игра предполагает овладение научным стилем языка, профессиональной терминологией, иноязычными речевыми клише экономической направленности.

Организациия. До проведения игры следует описать индивидуальную и групповую работу магистрантов в игре. На этапе подготовки к ролевой игре преподаватель выбирает тему, типичную профессиональную ситуацию и профессиональные аспекты и определяет цели ролевой игры. Далее вместе с магистрантами происходит распределение ролей, выбираются докладчики и эксперты.

Подготовка. В течение двух недель каждый докладчик самостоятельно изучает и анализирует учебную и научнотехническую литературу по выбранной теме на иностранном языке, готовит доклад и презентацию, используя профессиональную лексику, научный стиль языка, конкретные языковые структуры и интонационные образы. Для взаимодействия с другими участниками игры каждый магистрант готовит по несколько проблемных вопросов по темам других докладов. Экспертам следует изучить и проанализировать иноязычную литературу по всем темам докладов и подготовить список критериев оценивания выступления докладчиков.

Разминка. Предполагает вступительную речь ведущего на иностранном языке, озвучивание темы, цели игры, ее основных этапов.

Прочеесс. Данный этап характеризуется активным участием всех магистрантов экспериментальной группы в игровом процессе, имитирующем настоящую научнопрактическую конференцию. Докладчикам необходимо презентовать свой результат подготовительной самостоятельной работы доклад по выбранной тематике на иностранном языке, ответить на дополнительные вопросы и обсудить на заседании круглого стола различные вопросы профессиональной направленности в рамках темы конференции. Сам процесс подразумевает появление «незапрограммированных» языковых и профессиональных ситуаций, требующих мгновенных решений. Экспертам следовало внимательно слушать каждый доклад, оценивать его в соответствии с подготовленными критериями, задавать дополнительные вопросы докладчикам.

Последуюший анализ. После проведения учебно-ролевой игры наступает заключительный этап, который включает в себя рефлексию полученного игроками опыта ролевого взаимодействия по выходу из предложенной ситуации, урегулированию конфликтных отношений, реализации намеченных целей, подведение ведущим итогов, выделение наиболее значимых результатов, обобщение, установление взаимосвязей игровой ситуации с реальными жизненными ситуациями и личностными позициями участников. Происходит упорядочение, систематизация, оценка и анализ полученных решений совместно с обучающимися.

Анализ и замечания. В рамках этого фактора происходит сопоставление целей игры с полученными образовательными результатами, формулировка выводов об эффективности проделанной работы, осуществление контроля знаний, умений обучающихся по теме игры, в том числе учитывая результаты, полученные от экспертов, самооценка обучающихся об участии в игре, анализ приобретенных профессиональных знаний и умений, развития личностных качеств, самооценка преподавателя о проведении игры, достижении поставленных целей обучения.

Вариабельность. Данная ролевая (деловая) игра способна образовывать варианты, изменяться со сменой ролей, сменой темы и цели.

Экспериментальная работа проводилась в течение одного семестра. Проведенные беседы с магистрами показали, что, по их мнению, эффективно организованная учебно-ролевая игра обеспечивает высокую активность каждого участника процесса. Независимо от объема роли, каждый магистр участвует в коммуникативной дея- 
тельности. Учет профессионально ориентированных ситуаций для создания учебноролевых игр дает возможность каждому участнику почувствовать себя настоящим специалистом, проверить собственные возможности, приобрести необходимые в дальнейшей профессиональной деятельности навыки и умения, совершенствовать межкультурную и иноязычную коммуникативную компетенции.

На основе применения метода педагогического наблюдения и анкетирования, сделаем вывод, что использование учебноролевых игр дает магистрам возможность не только изучать иностранный язык, но и совершенствовать свою профессиональную компетенцию, формировать и развивать профессионально-личностные компетенции, умения и навыки, необходимые в дальнейшей профессиональной деятельности.

Ролевая игра является моделью общения, имеет много возможностей и характе- ристик, мотивирует студентов принимать активное участие во всем, что происходит в рамках поставленной профессионально ориентированной учебной ситуации, способствует расширению ассоциативной базы в процессе усвоения нового материала, создает положительную атмосферу на занятии и обеспечивает гармоничную коллективную деятельность, а значит - повышает эффективность обучения иностранному языку студентов-магистров экономических специальностей.

В конце семестра было проведено повторное тестирование и анкетирование, которые показали, что уровень мотивации, формирования профессиональной иноязычной компетенции, интереса к предмету повысился и в экспериментальной, и в контрольной группах. Однако показатели в экспериментальной группе значительно выше (рис. 2).

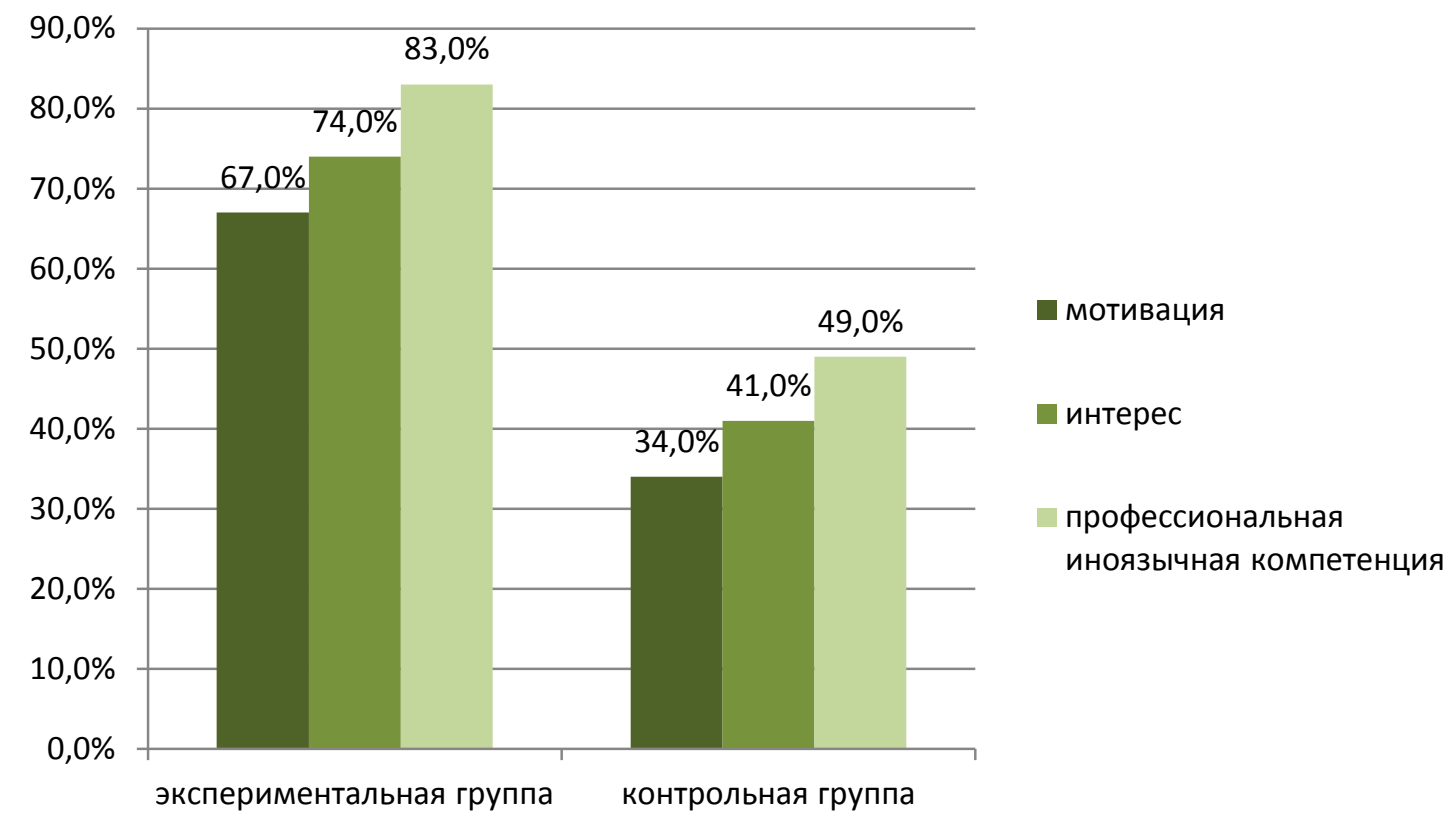

Рис. 2. Уровень сформированности профессиональной иноязычной коммуникативной компетенции, мотивации к обучению, степени вовлеченности в процесс обучения и интереса к изучению предмета в конце эксперимента

Fig. 2. The level of formation of professional foreign-language communicative competence and learning motivation, the degree of involvement in the learning process and interest in the study of the subject at the end of the experiment 
Таким образом, метод тестирования позволил определить, что использование учебно-ролевых игр позволяет существенно повысить качество языковой подготовки будущих экономистов, помогает формировать профессиональную иноязычную коммуникативную компетенцию молодых специалистов, что способствует их успешной профессионализации, профессиональной мобильности, активности и конкурентоспособности на рынке труда, развитию профессиональной карьеры.

Сопоставив результаты обучения в экспериментальной и контрольной группах, был сделан вывод о том, что использование ролевых игр при обучении иностранному языку магистрантов неязыкового вуза позволяет:

- создавать положительную мотивацию к овладению профессиональными знаниями на иностранном языке;

- формировать потребность в самовыражении и самореализации в деятельности, направленной на создание творческого продукта;

- формировать умения поиска, получения, восприятия, осознания, запоминания, анализа, обобщения, сравнения, выявления причинно-следственных связей при работе с учебными материалами профильно-ориентированного содержания;

- формировать умения, преобразовывать научно-теоретические знания на иностранном языке по выбранному направлению подготовки в творческий продукт;

- формировать умения самоорганизации процесса изучения дидактического материала профильно-ориентированного содержания;

- активизировать индивидуальные особенности магистрантов в процессе учебной, исследовательской, коммуникативной деятельности;

- формировать умения преобразовывать содержание разножанровых профильно-ориентированных материалов на иностранном языке в личностно-значимый продукт творческий деятельности; презентовать результаты работы;
- формировать понимание своей роли в социальной и профессиональной среде, понимание значимости выбранной профессии, ее престижности в обществе;

- формировать способность осмысливать проблемы, принимать правильные решения в соответствии с принятыми нравственными нормами и нести ответственность за результаты деятельности, в том числе профессиональной;

- развивать способности обучающегося к осмыслению и самоанализу, самооценке собственных способностей и возможностей;

- формировать умения выбирать на основе приобретенного опыта коммуникативной деятельности оптимальные методы и приемы работы с дидактическими материалами профильно-ориентированного содержания.

Заключение (Conclusions). Учебноролевая игра, и деловая игр, в частности, позволяют задать в обучении предметный и социальный контекст будущей профессиональной деятельности и смоделировать более адекватные в сравнении с традиционными методами обучения условия формирования будущего специалиста. В этих условиях:

1) усвоение нового знания накладывается на канву будущей профессиональной деятельности;

2) обучение приобретает совместный коллективный характер;

3) развитие личности специалиста осуществляется в результате подчинения двум типам норм: нормам компетентных предметных действий и нормам социальных отношений коллектива.

\section{Список литературы}

Азимов Э.Г., Щукин А.Н. Новый словарь методических терминов и понятий (теория и практика обучения языкам). М.: Издательство ИКАР, 2009. С. 264.

Деркач А.А., Щербак С.Ф. Педагогическая эвристика. Искусство овладения иностранным языком. М.: Педагогика, 1991. 218 с.

Исламова Т. Ролевая игра как один из интерактивных методов обучения иностранному 
языку // Наука и Мир. 2016. Т. 3. № 2. C. $140-141$.

Кондюрина И.М., Гришина Е.В., Шевелева В.В. Обучение иноязычной научной коммуникации магистров в неязыковом вузе. // Социокультурное пространство России и зарубежья: общество, образование, язык. 2018. № 7. C. 107-121.

Корниенко А.Н. Содержание профессионально-ориентированного обучения экономистов иностранному языку на основе метода проектов // Вестник алтайской науки. 2014. № 2-3 (20-21). C. 110-115.

Курченкова Е.А. Урок-конференция на английском языке как средство формирования профессиональной иноязычной компетенции // Коммуникативные аспекты современной лингвистики и лингводидактики: Материалы международной научной конференции. Федер. гос. авт. образоват. учреждение высш. проф. образования «Волгогр. гос. ун-т», Ин-т филологии и межкультурной коммуникации. 2016. C. 112-118.

Нелюбина Е.А. Ролевая игра как интерактивный метод обучения иностранным языкам в неязыковом вузе // Ученые записки Казанского филиала «Российского государственного университета правосудия». 2014. Т. 10. С. 217-222.

Скалкин В.Л. Обучение диалогической речи. К.: Радянська школа, 2005. 158 с.

Семенова Г.В. Модернизация содержания языкового образования на уровне профессиональной подготовки студентов магистратуры // Известия Тульского государственного университета. Педагогика. 2018. № 2. С. 93-100.

Семенова Г.В. Роль научноисследовательской работы студентов при подготовке к профессиональной мобильности // Известия Тульского государственного университета. Педагогика. 2015. № 2. С. 136-139.

Павловская Ю.В. Особенности процесса формирования иноязычной коммуникации в ролевой игре // Международный журнал гуманитарных и естественных наук. 2016. №1. C. 130-132. URL: https://cyberleninka.ru/article/n/ osobennosti-protsessa-formirovaniya-

inoyazychnoy-kommunikatsii-v-rolevoy-igre (дата обращения: 13.04.2019).

Чудайкина Г.М., Логинова Н.Ю., Костоварова В.В. Использование ролевых игр в преподавании иностранного языка в вузах туризма и сервиса // Вестник ассоциации вузов туризма и сервиса. 2017 . №1. С. 13-20. DOI: 10.22412/1999-5644-11-1-2

Юханов Г.В., Гордеев Т.Ю. Учебноролевые игры экономической направленности // Вестник ТГТУ. 2008. №2. С. 405-408. URL: https:// cyberleninka.ru/article/n/uchebno-rolevyeigry-ekonomicheskoy-napravlennosti (дата обращения: 04.12.2019).

Ярунина С.А. Ролевые игры при обучении иностранному языку // Вестник Майкопского государственного технологического университета. 2017. №4. C. 78-82. URL: https://cyberleninka.ru/article/n/rolevye-igry-priobuchenii-inostrannomu-yazyku (дата обращения: 13.04.2019).

Brumfit Ch., Johnson K. (2008), The communicative approach to language teaching, Oxford Univ. Press, Oxford, UK.

Ladousse G. P. (1987), Role play, Oxford University Press, Oxford, UK.

Littlewood W. (2007), Communicative language teaching, Cambridge Univ. Press, Cambridge, UK.

Livingstone C. (1983), Role play in language learning, Longman, London, UK.

\section{References}

Azimov, E.G. and Shchukin, A.N. (2009), Novyj slovar' metodicheskih terminov i ponjatij (teorija i praktika obuchenija jazykam) [New dictionary of methodological terms and concepts (theory and practice of language teaching)], Icarus Publishing House, Moscow, Russia.

Derkach, A.A. and Shcherbak, S.F. (1991), Pedagogicheskaya evristika. Iskusstvo ovladeniya inostrannym yazykom [Teaching heuristics. The art of mastering a foreign language], Pedagogika, Moscow, Russia.

Islamova, T. (2016), "Role playing game as one of the interactive methods of teaching a foreign language", Nauka i Mir, 3(2), 140-141. (In Russian).

Kondjurina, I.M., Grishina, E.V. and Sheveleva, V.V. (2018), "Teaching foreign language scientific communication masters in nonlinguistic University", Sociokul'turnoe prostranstvo Rossii $i$ zarubezh'ja: obshhestvo, obrazovanie, jazyk, 7, 107-121. (In Russian).

Kornienko, A.N. (2014), "The content of professionally oriented training of economists in a foreign language based on the project method", Vestnik altajskoj nauki, 2-3 (20-21), 110-115. (In Russian). 
Kurchenkova, E.A. (2016), Lessonconference in English as a means of forming professional foreign language competence, Коттиnikativnye aspekty sovremennoj lingvistiki $i$ lingvodidaktiki: Materialy mezhdunarodnoj nauchnoj konferencii. Feder. gos. avt. obrazovat. uchrezhdenie vyssh. prof. obrazovaniya «Volgogr. gos. un-t», In-t filologii i mezhkul'turnoj kommunikacii, 112-118. (In Russian).

Neljubina, E.A. (2014), "Role-playing game as an interactive method of teaching foreign languages in a non-linguistic university", Uchenye zapiski Kazanskogo filiala "Rossijskogo gosudarstvennogo universiteta pravosudija», 10, 217-222. (In Russian).

Skalkin, V.L. (2005), Obuchenie dialogicheskoj rechi [Conversational Speech Training], Radjans'ka shkola, Kiev, Ukraine.

Semenova, G.V. (2018), "Modernization of the content of language education at the level of professional training of graduate students", Izvestija Tul'skogo gosudarstvennogo universiteta. Pedagog$i k a, 2$, 93-100. (In Russian).

Semenova, G.V. (2015), "The role of the scientific-research work of students in preparation for professional mobility", Izvestija Tul'skogo gosudarstvennogo universiteta. Pedagogika, 2, 136-139. (In Russian).

Pavlovskaya, Yu.V. (2016), Features of the process of forming foreign-language). communication in role-playing game, Mezhdunarodnyj zhurnal gumanitarnyh $i$ estestvennyh nauk, 1, 130-132. Available at:

URL: https://cyberleninka.ru/article/n/osobennostiprotsessa-formirovaniya-inoyazychnoy-

kommunikatsii-v-rolevoy-igre (Accessed 13 April 2019).

Chudajkina, G.M., Loginova, N.Yu. and Kostovarova, V.V. (2017), "Using role-playing games in teaching a foreign language at tourism and service universities", Vestnik associacii vuzov turizma i servisa, 1, 13-20. DOI: 10.22412/19995644-11-1-2 (In Russian).

Yukhanov, V.G. and Gordeev, T.Y. (2008), "Educational role-playing games economic focus", Vestnik TGTU, 2, 405-408. (In Russian).

Yarunina, S.A. (2017), "Role-playing games in learning a foreign language", Vestnik Majkopskogo gosudarstvennogo tekhnologicheskogo universiteta, 4, 78-82. Available at: URL: https://cyberleninka.ru/article/n/rolevye-igry-priobuchenii-inostrannomu-yazyku (Accessed 13 April 2019). (In Russian).

Brumfit, Ch. and Johnson, K. (2008), The communicative approach to language teaching, Oxford University Press, Oxford, UK.

Ladousse, G.P. (1987), Role play, Oxford University Press, Oxford, UK.

Littlewood, W. (2007), Communicative language teaching, Cambridge Univ. Press, Cambridge, UK.

Livingstone, C. (1983), Role play in language learning, Longman, London, UK.

Информация о конфликте интересов: автор не имеет конфликта интересов для декларации.

Conflicts of Interest: the author has no conflict of interests to declare.

\section{Данные автора:}

Семенова Галина Владимировна, кандидат педагогических наук, доцент кафедры иностранных языков, Тульский государственный университет. ORCID: 0000-0002-9693-1031.

\section{About the author:}

Galina V. Semenova, $\mathrm{PhD}$ in Pedagogy, Associate Professor of the Department of Foreign Languages, Tula State University. ORCID: 0000-0002-96931031. 